\title{
Potential novel biomarkers of cardiovascular dysfunction and disease: cardiotrophin-1, adipokines and galectin-3
}

Simona Hogas', Stefana C. Bilha², Dumitru Branisteanu², Mihai Hogas³ ${ }^{3}$ Abduzhappar Gaipov", Mehmet Kanbay ${ }^{5}$, Adrian Covic ${ }^{1}$

\author{
${ }^{1}$ Nephrology Department, Dialysis and Renal Transplant Center, "C.I. Parhon" \\ University Hospital, "Grigore T. Popa" University of Medicine and Pharmacy, lasi, \\ Romania \\ 2Endocrinology Department, "Sf. Spiridon” Hospital, “Grigore T. Popa” University \\ of Medicine and Pharmacy, lasi, Romania \\ ${ }^{3}$ Physiology Department, "Grigore T. Popa" University of Medicine and Pharmacy, lasi, \\ Romania \\ ${ }^{4}$ Extracorporeal Hemocorrection Unit, JSC "National Scientific Medical Research \\ Center", Astana, Kazakhstan \\ ${ }^{5}$ Department of Medicine, Division of Nephrology, Koc University School of Medicine, \\ Istanbul, Turkey
}

Submitted: 7 October 2015

Accepted: 30 December 2015

Arch Med Sci 2017; 13, 4: 897-913

DOI: https://doi.org/10.5114/aoms.2016.58664

Copyright @ 2016 Termedia \& Banach

\begin{abstract}
Cardiovascular disease is one of the main burdens of healthcare systems worldwide. Nevertheless, assessing cardiovascular risk in both apparently healthy individuals and low/high-risk patients remains a difficult issue. Already established biomarkers (e.g. brain natriuretic peptide, troponin) have significantly improved the assessment of major cardiovascular events and diseases but cannot be applied to all patients and in some cases do not provide sufficiently accurate information. In this context, new potential biomarkers that reflect various underlying pathophysiological cardiac and vascular modifications are needed. Also, a multiple biomarker evaluation that shows changes in the cardiovascular state is of interest. This review describes the role of selected markers of vascular inflammation, atherosclerosis, atherothrombosis, endothelial dysfunction and cardiovascular fibrosis in the pathogenesis and prognosis of cardiovascular disease: the potential use of cardiotrophin-1, leptin, adiponectin, resistin and galectin-3 as biomarkers for various cardiovascular conditions is discussed.
\end{abstract}

Key words: cardiovascular disease, cardiotrophin-1, adipokines, galectin-3.

\section{Introduction}

According to the World Health Organization (WHO), cardiovascular diseases (CVD) are currently the leading cause of morbidity and mortality worldwide. The burden of cardiovascular death is also very high in Europe, with the highest rates being encountered in Central and Eastern Europe [1]. The main causes of cardiovascular (CV) death are ischemic heart disease and cerebrovascular disease. A significant proportion of these deaths may be prevented through better surveillance and prophylaxis; risk stratification is an important part of this strategy for timely

\author{
Corresponding author: \\ Stefana Bilha \\ Department of Endocrinology \\ "Sf. Spiridon" Hospital \\ "Grigore T. Popa" University \\ of Medicine and Pharmacy \\ No. 1 Independentei Blvd. \\ 700111, lasi, Romania \\ Phone: +40 752092550 \\ Fax: +40 232229940 \\ E-mail: \\ stefanabilha@gmail.com
}


interventions and long-term targeted management [2].

CV risk assessment models are based on traditional risk factors such as age, sex, smoking, blood pressure, diabetes, total cholesterol, HDL cholesterol, family history, etc. Risk models such as the US Framingham risk score or the European SCORE model evaluate CV risk in "apparently healthy" subjects (without already established CVD or diabetes) [3]. Although these are first-line tools for patients who need stepped-up prevention, limitations are inevitable: "intermediate" risk patients remain a heterogeneous category; frequently patients with an apparently low risk have subclinical atherosclerosis and vascular dysfunction that would benefit from a more intense intervention. In addition, CV risk may also be underestimated in patients with central obesity $[3,4]$.

The search for molecules that could help improve CVD assessment in primary and secondary care is continuous and prolific. Despite sustained efforts and a very large panel of candidates for biomarkers, very few molecules have proven their utility in clinical practice. Standardly used biomarkers for CVD include natriuretic peptides (brain natriuretic peptide (BNP), and N-terminal prohormone of brain natriuretic peptide (NT-proBNP)), troponins, C-reactive protein (CRP) and cardiac enzymes. The Food and Drug Administration (FDA) list of validated cardiovascular biomarker includes the above and also galectin- 3 and ST-2 (Table I) [5].

All these prediction, diagnosis and prognosis biomarkers proved to be the best so far but still have their pros and cons. BNP and NT-proBNP have similar clinical performance in diagnosing heart failure (HF) but NT-proBNP may be preferred to BNP due to its longer plasma half-life and its better outcome prognosis in the Valsartan Heart Failure Trial [6]. Natriuretic peptides (NP) best rule out cardiac dysfunction in patients with acute dyspnea presenting to the emergency room and are useful in establishing the prognosis and disease severity in acute and chronic HF. BNP has also been validated for risk stratification in acute coronary syndromes (ACS). However, NP are greatly influenced by non-cardiac factors, one of the most prominent being kidney function, and are not useful in discriminating the etiology of HF [7-9]. Cardiac troponins (cTn) are first line biomarkers for ACS, having clinical sensitivity and myocardial specificity. CTn are the gold-standard markers for myocardial injury; however, brief elevations can occur in non-ACS conditions. Also, cTn are not able to provide differential diagnosis between ischemic, inflammatory and traumatic myocardial injury [10]. Cardiac CRP (cCRP) is a high-sensitivity CRP assay recently validated by the FDA with evidence of efficacy and extended use for CV risk assessment/stratification. It should be interpreted with caution in the presence of systemic inflammatory conditions, acute infections, trauma and others (Table I) [11, 12]. Galectin-3 and ST-2 are two cardiac biomarkers recently cleared by the FDA and also recommended by the American College of Cardiology Foundation/American Heart Association (ACCF/AHA) guidelines for use as an aid in the management of patients with HF. Galectin-3 should be interpreted with caution in patients with altered kidney function and/or cancer $[8,13,14]$. ST-2 also rises in inflammatory and pulmonary diseases (Table I) [13]. Regarding cardiac enzymes (creatine kinase (CK), creatine kinase muscle/brain (CK-MB) enzyme, lactic dehydrogenase (LDH) and myoglobin), these are to be used as an aid in the diagnosis of acute myocardial infarction (AMI). Their limitations are presented in Table I $[15,16]$

Recently, new molecules regulating atherosclerosis, inflammation, endothelial dysfunction (ED), fibrosis and thrombosis have been proposed as biomarkers for evaluating CV risk and disease, especially for risk stratification. Adding these biomarkers to established CV risk assessment models could provide a significant increment to the predictive value of these models. Novel CV biomarkers should be cost-efficient, valid, reproducible, reliable and accurate. They should be capable of independently predicting CVD and also of providing more information than traditional biomarkers [3, 4].

Several new molecules have been proposed as biomarkers for evaluating CVD. We conducted a literature search to select the best novel biomarkers that predict the development of new CVD, differentiate CVD from other diseases, evaluate the severity of CVD and might also be considered prognostic markers. We found 19 novel biomarkers that have been studied in CVD (Table II).

We chose here to review cardiotrophin-1 (CT-1) as it is a promising biomarker for hypertensive heart disease, where it brings significant additional information to that provided by NP. Also, the adipokines leptin, adiponectin and resistin have been proposed as biomarkers for various cardiovascular conditions and are discussed below, where clarifications regarding their prognostic value are made. Finally, we chose here to discuss the strong and weak points of galectin-3 and its utility in comparison to other biomarkers of HF in order to clarify the indications for galectin-3 determination. Table III illustrates which of these five biomarkers could be used as potential predictors for vascular inflammation, atherosclerosis, ED and cardiovascular fibrosis.

As the literature is replete with clinical information on biomarkers which are often inconsistent, 
Table I. Cardiovascular biomarkers validated by FDA and their limitations

\begin{tabular}{|c|c|c|}
\hline Biomarker & FDA indication* & Limitations \\
\hline BNP/NT-proBNP & $\begin{array}{l}\text { Differentiating cardiac dyspnea from dyspnea of } \\
\text { non-cardiac origin }\end{array}$ & \multirow{3}{*}{$\begin{array}{l}\text { 1) Not useful in assessing HF etiology } \\
\text { 2) Influenced by age, gender, weight, fluid } \\
\text { load, physical exercise } \\
\text { 3) Wide range of other conditions } \\
\text { associated with increased NP: } \\
\text { Cardiac-other than HF and ACS: } \\
\text { - valvular heart disease } \\
\text { - pericardial disease } \\
\text { - atrial fibrillation } \\
\text { - myocarditis } \\
\text { - cardiac surgery } \\
\text { - cardioversion } \\
\text { Non-cardiac: } \\
\text { - anemia } \\
\text { - chronic kidney disease } \\
\text { - pulmonary disease: pulmonary } \\
\text { hypertension, embolism, obstructive } \\
\text { sleep apnea, severe pneumonia } \\
\text { - sepsis } \\
\text { - critical illness } \\
\text { - severe burns } \\
\text { - cancer chemotherapy [7-9] }\end{array}$} \\
\hline NT-proBNP & $\begin{array}{l}\text { 1) Aid in the diagnosis of congestive HF } \\
\text { 2) Assessment of severity in individuals } \\
\text { suspected of chronic HF } \\
\text { 3) Aid in the risk stratification of HF } \\
\text { 4) Risk stratification of patients with ACS and } \\
\text { chronic HF } \\
\text { 5) Assessment of increased risk of } \\
\text { cardiovascular events and mortality in } \\
\text { patients with stable CHD at risk for HF }\end{array}$ & \\
\hline BNP & $\begin{array}{l}\text { 1) Prediction of survival after ACS } \\
\text { 2) Assessment of HF severity in congestive } \\
\text { heart failure }\end{array}$ & \\
\hline $\begin{array}{l}\text { Troponin T/ } \\
\text { troponin I }\end{array}$ & $\begin{array}{l}\text { 1) Aid in the diagnosis of ACS } \\
\text { 2) Risk stratification in ACS } \\
\text { 3) Assessing cardiac risk in CKD }\end{array}$ & $\begin{array}{l}\text { Conditions associated with increased } \\
\text { troponins other than ACS (selected): } \\
\text { Cardiovascular: } \\
\text { - endocarditis, pericarditis, myocarditis } \\
\text { - acute heart failure } \\
\text { - acute aortic dissection } \\
\text { - stroke } \\
\text { - coronary vasospasm } \\
\text { - electrical cardioversion } \\
\text { - left ventricular hypertrophy } \\
\text { - dilated/hypertrophic cardiomyopathy } \\
\text { - implantable defibrillator } \\
\text { Other: } \\
\text { - sepsis } \\
\text { - rhabdomyolysis } \\
\text { - pulmonary embolism } \\
\text { - end-stage renal disease } \\
\text { - chemotherapy [10] }\end{array}$ \\
\hline CRP & $\begin{array}{l}\text { 1) Conventional CRP-evaluation of infection/ } \\
\text { tissue injury/inflammatory disorders- } \\
\text { for diagnosis/therapy/monitoring } \\
\text { of inflammatory disorders } \\
\text { 2) hsCRP-evaluation of conditions thought to be } \\
\text { associated with inflammation in otherwise } \\
\text { healthy individuals } \\
\text { 3) Cardiac CRP: } \\
\text { - aid for identification and stratification } \\
\text { of individuals at risk for CVD } \\
\text { - prognosis of recurrent events in stable } \\
\text { CHD/ACS }\end{array}$ & $\begin{array}{l}\text { Low specificity } \\
\text { Conditions associated with increased } \\
\text { hsCRP, other than CVD: } \\
\text { - acute infection } \\
\text { - trauma } \\
\text { - systemic inflammatory diseases: } \\
\text { rheumatoid arthritis, lupus } \\
\text { erythematosus } \\
\text { - postmenopausal hormone replacement } \\
\text { therapy [12] }\end{array}$ \\
\hline Galectin-3 & $\begin{array}{l}\text { Aid in assessing the prognosis of patients } \\
\text { diagnosed with chronic HF }\end{array}$ & $\begin{array}{l}\text { Strongly correlated with kidney function } \\
\text { Falsely elevated results: } \\
\text { - hemolysis } \\
\text { - cancer } \\
\text { - conditions associated with organ fibrosis } \\
\text { - high levels of gamma-globulins/ } \\
\text { rheumatoid factor [13] }\end{array}$ \\
\hline
\end{tabular}


Table I. Cont.

\begin{tabular}{|c|c|c|}
\hline Biomarker & FDA indication* & Limitations \\
\hline ST-2 & $\begin{array}{l}\text { Aid in assessing the prognosis of patients } \\
\text { diagnosed with chronic HF }\end{array}$ & $\begin{array}{l}\text { Other causes of elevated ST-2: } \\
\text { - systemic lupus erythematosus } \\
\text { - asthma } \\
\text { - inflammatory conditions (septic shock, } \\
\text { pneumonia) } \\
\text { - chronic obstructive pulmonary disease } \\
\text { - trauma [13] }\end{array}$ \\
\hline CK & Aid in the diagnosis of AMI & $\begin{array}{l}\text { Lack of specificity } \\
\text { Causes of elevated CK other than AMI: } \\
\text { - trauma } \\
\text { - surgery } \\
\text { - myxedema } \\
\text { - diabetic ketoacidosis } \\
\text { - hypothermia } \\
\text { - polymyositis } \\
\text { - Duchenne muscular dystrophy } \\
\text { - intramuscular injections [16] }\end{array}$ \\
\hline CK-MB & Aid in the diagnosis of AMI & $\begin{array}{l}\text { Specific for myocardial cell injury but not } \\
\text { for AMI } \\
\text { Causes of elevated CK-MB other than AMI } \\
\text { - myocarditis } \\
\text { - cardiac trauma } \\
\text { - cardiac surgery } \\
\text { - endomyocardial biopsy } \\
\text { - athletes during exercise [16] }\end{array}$ \\
\hline LDH & Aid in the diagnosis of AMI & $\begin{array}{l}\text { Limited specificity } \\
\text { Causes of elevated LDH other than AMI: } \\
\text { - hemolysis } \\
\text { - megaloblastic anemia } \\
\text { - renal cortical damage } \\
\text { - muscular dystrophies } \\
\text { - carcinomas [112] }\end{array}$ \\
\hline Myoglobin & Aid in the diagnosis of AMI & $\begin{array}{l}\text { Limited specificity in patients with: } \\
\text { - kidney disease } \\
\text { - muscle trauma } \\
\text { Not useful in patients presenting more } \\
\text { than } 24 \mathrm{~h} \text { after onset of symptoms [15] }\end{array}$ \\
\hline
\end{tabular}

ACS - acute coronary syndrome, AMI - acute myocardial infarction, CHD - coronary heart disease, CKD - chronic kidney disease, $C V D$ - cardiovascular disease, $H F$ - heart failure, hSCRP-high-sensitivity C-reactive protein. *Source for provided indications: www.fda.gov.

this review is intended to clarify which of these biomarkers deserve further analysis and what are their potential indications of use.

\section{Cardiotrophin-1}

$\mathrm{CT}-1$ is a $21.5-\mathrm{kDa}$ protein, a member of the interleukin 6 (IL-6) family of cytokines [17], first described by Pennica et al. [17] to induce cardiomyocyte hypertrophy by atrial natriuretic peptide secretion and organization of myosin light chains into sarcomeres.

\section{Pathophysiology and experimental studies}

CT-1 is a survival promoter cytokine that is upregulated in cardiomyocytes and cardiac fibroblasts in response to mechanical (ventricular stretch), humoral (angiotensin II, aldosterone, catecholamines), metabolic (glucose, insulin) and hypoxic stress. In acute stress, CT-1 promotes cell survival. However, if stressful signals persist, chronic upregulation of CT-1 leads to cardiomyocyte hypertrophy and, finally, left ventricular dysfunction [4]. CT-1 exerts its biological activity through the leukemia inhibitory factor receptor $\beta$ (LIFR $\beta$ )/glycoprotein 130 (gp130) heterodimer receptor that further activates multiple signaling pathways with different consequences (Figure 1): Janus kinase/signal transducer and activator of transcription 3 (JAK/STAT3) promotes ventricular hypertrophy while p42/44 mitogen-activated protein kinase (p42/44 MAPK) and the phosphoinositide 3-kinase/Akt (PI3K/Akt) pathways inhibit apoptosis and promote cardiomyocyte survival.

It may be possible that myocyte hypertrophy is also mediated by the activation of mitogen-activated protein kinase kinase 5/extracellular-signal-regulated kinase 5 (MEK5/ERK5 pathway) [4, 
Table II. Potential cardiovascular biomarkers regulating atherosclerosis, inflammation, endothelial dysfunction and fibrosis in cardiovascular disease

\begin{tabular}{|c|c|c|c|c|c|c|}
\hline $\begin{array}{l}\text { Biomarkers called } \\
\text { "cardiovascular" }\end{array}$ & $\begin{array}{l}\text { Number } \\
\text { of articles }\end{array}$ & $\begin{array}{l}\text { Prediction } \\
\text { of CVD }\end{array}$ & $\begin{array}{l}\text { Differential } \\
\text { diagnosis }\end{array}$ & $\begin{array}{l}\text { Disease } \\
\text { severity }\end{array}$ & $\begin{array}{l}\text { Outcome and } \\
\text { prognosis }\end{array}$ & $\begin{array}{c}\text { Treatment } \\
\text { effectiveness }\end{array}$ \\
\hline MR-proANP & 14 & + & & + & + & \\
\hline Cardiotrophin-1 & 111 & + & + & + & + & + \\
\hline GDF-15 & 174 & + & & + & + & + \\
\hline IMA & 219 & + & & + & + & \\
\hline Lp-PLA2 & 241 & + & & & + & \\
\hline Pentraxin 3 & 326 & & & + & & + \\
\hline NT-proBNP & 418 & + & & + & + & + \\
\hline Creatine kinase & 692 & + & + & + & + & + \\
\hline ADMA & 797 & + & & & + & \\
\hline CT-I and CT-T & 868 & + & + & + & + & + \\
\hline Resistin & 945 & + & & + & + & + \\
\hline Galectin-3 & 967 & + & + & + & + & + \\
\hline PON1 & 1200 & + & & & + & \\
\hline BNP & 1700 & + & & + & & \\
\hline Homocysteine & 3592 & + & & + & & \\
\hline IL-6 & 4178 & + & & & & \\
\hline Adiponectin & 5308 & + & & + & + & \\
\hline CRP & 6076 & & + & + & + & + \\
\hline Leptin & 6757 & + & & + & + & \\
\hline
\end{tabular}

ADMA - asymmetric dimethylarginine, BNP-B-type natriuretic peptide, CRP-C-reactive protein, CT-I and CT-T-cardiac-specific troponins I and T, GDF-15 - growth differentiation factor 15, IL-6 - interleukin-6, IMA - ischemia modified albumin, Lp-PLA2 - lipoprotein-associated phospholipase A2, MR-proANP-mid-regional pro-atrial natriuretic peptide, NT-proBNP-N-terminal pro-B-type natriuretic peptide, PON1 - paraoxonase 1

Table III. Novel biomarkers - players in cardiovascular dysfunction

\begin{tabular}{|c|c|c|c|c|c|}
\hline Biomarker & $\begin{array}{l}\text { Endothelial } \\
\text { dysfunction }\end{array}$ & Atherosclerosis & Inflammation & Fibrosis & Atherothrombosis \\
\hline Cardiotrophin-1 & + & + & & + & \\
\hline Leptin & + & + & + & & + \\
\hline Adiponectin & + & + & + & & + \\
\hline Resistin & + & + & + & + & + \\
\hline Galectin-3 & & + & + & + & \\
\hline
\end{tabular}

18-20]. CT-1 is also expressed in vascular endothelial cells and has direct vascular effects, resulting in atherogenesis, vascular dysfunction, arterial stiffness, and increased blood pressure [21-23]. Overall, CT-1 is a potent profibrotic agent for the heart and vessels [4, 23].

\section{Clinical studies}

CT-1 is a key link between hypertension, left ventricular hypertrophy (LVH) and HF. In a metaanalysis performed by Song et al. [24] Cardiotrophin-1 levels were highest in hypertensive patients with $\mathrm{LVH}$ and HF compared to controls, followed by hypertensive patients with LVH with- out HF and hypertensive patients without LVH or HF. Moreover, CT-1 directly correlates with left ventricular mass index (LVMI) in hypertensive patients independently of systolic blood pressure: patients with CT-1 above the cut-off value of $39 \mathrm{fmol} / \mathrm{ml}$ are six times more likely to have LVH. Thus CT-1 could be applied in the screening and diagnosis of hypertensive heart disease, helping to select patients that would best benefit from echocardiography [25].

Regarding CT-1 and HF, Talwar et al. [26] were the first to report that plasma CT-1 levels correlate with the degree of systolic dysfunction in HF patients. Plasma CT-1 levels are also increased in patients with diastolic HF and positively correlate with left 


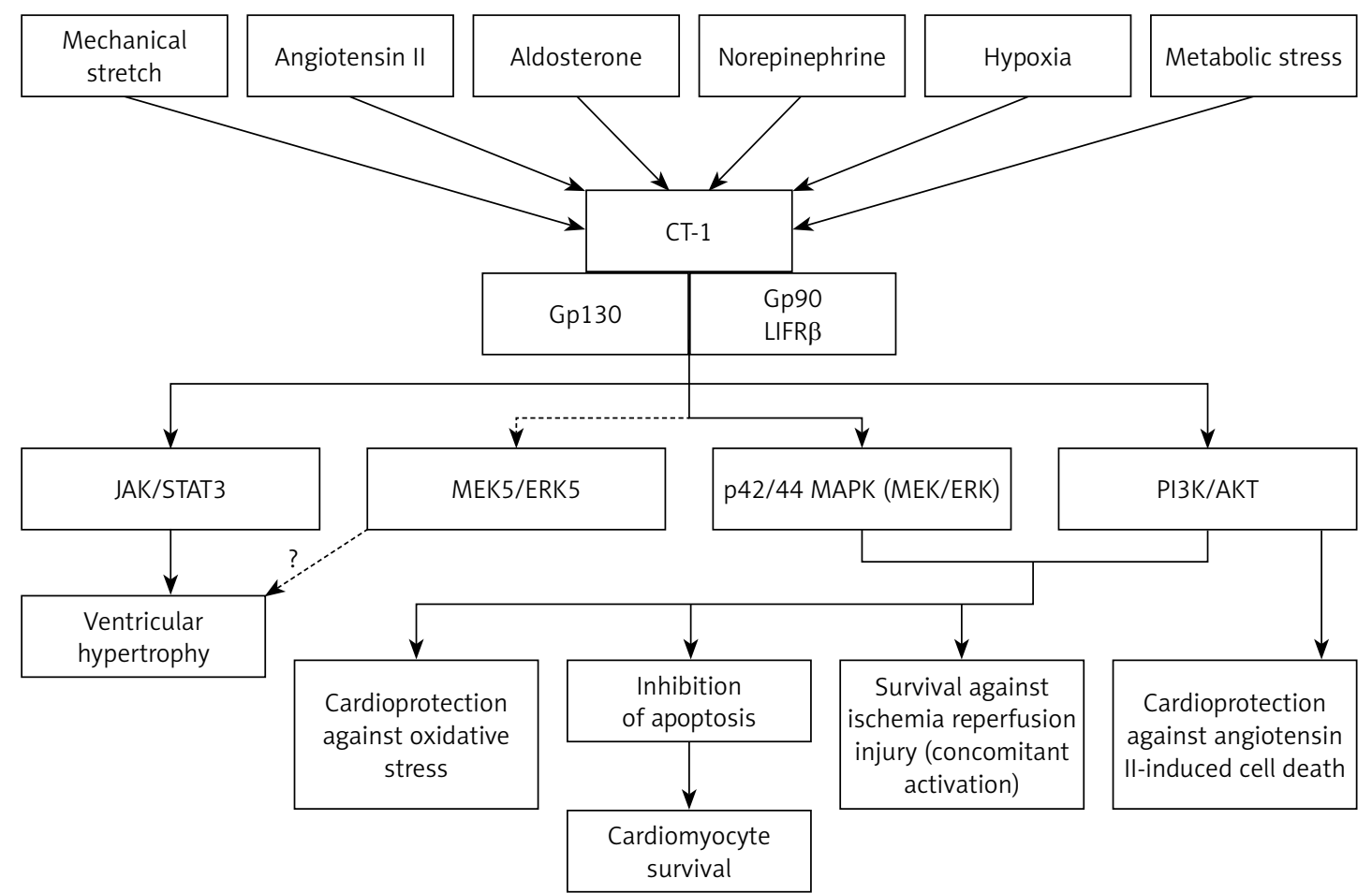

Figure 1. Schematic representation of CT-1 signaling pathways and their different effects on the cardiac cell (see text for abbreviations)

ventricular filling pressures [27]. Furthermore, CT-1 levels significantly predict overt HF in hypertensive patients: CT-1 concentration positively correlates with NT-proBNP and negatively correlates with left ventricular ejection fraction $[28,29]$. The cut-off value for CT-1 plasma levels of $152 \mathrm{pg} / \mathrm{ml}$ has $77 \%$ sensitivity and $85 \%$ specificity for detecting the occurrence of overt HF in hypertensive patients [28]. Also, CT-1 is a predictor of mortality in chronic HF irrespective of etiology and independently of BNP [30]. Thresholds and potential indications for CT-1 use are presented in Table IV.

CT-1 could also be used as a monitoring tool for therapeutic management in hypertensive heart disease patients: LVH and CT-1 levels had a tendency to decrease after losartan treatment rather than after treatment with atenolol [31].

Finally, although a promoter of ED, studies failed to show an association between CT-1 and coronary heart disease (CHD) [32].

\section{Cardiotrophin-1 vs. standardly used biomarkers}

With regards to predicting $\mathrm{LVH}$ onset in hypertensive patients, CT-1 performs much better than NT-proBNP, with $70 \%$ sensitivity and $75 \%$ specificity for CT-1 cut-off value vs. $40 \%$ sensitivity and $61 \%$ specificity for NT-proBNP cut-off value [25].

Even though NT-proBNP is the gold-standard biomarker for HF diagnosis, studies have shown that the association between CT-1 and NT-proBNP is superior to NT-proBNP alone in assessing the presence of $\mathrm{HF}$ in hypertensive patients [28, 29]. CT-1 is less specific but more sensitive than NT-proBNP for detecting stage C HF in hypertensive patients, thus improving NT-proBNP sensitivity for detecting HF [29]. The combination CT-1 and BNP is better than either marker alone in predicting mortality in chronic HF [30].

Also, CT-1 may compensate for some of the downsides of NT-proBNP: CT-1 is not influenced by kidney function, while NT-proBNP negatively correlates with estimated glomerular filtration rate (eGFR) [29]. Also, CT-1 correlates with echocardiographic parameters of LVH (LVMI), while NT-proBNP does not correlate with $\mathrm{LVH}$ in hypertensive patients with normal cardiac function. Thus, NT-proBNP is not useful in assessing hypertensive heart disease in patients with normal systolic function [25].

In summary, CT-1 is a promising biomarker for predicting maladaptive hypertensive heart disease in hypertensive patients. CT-1 could become a predictor of arterial hypertension prognosis in terms of occurrence of LVH in hypertensive patients with normal systolic function. Also, CT-1 could bring incremental power when used together with NT-proBNP for assessing HF in hypertension and for the prognosis of chronic HF. Eventually, circulating CT-1 determination could also be useful for establishing optimal individualized therapy and for monitoring disease evolution in these patients. 
Table IV. Novel potential biomarkers - indications and thresholds

\begin{tabular}{|c|c|c|c|}
\hline Biomarker & $\begin{array}{c}\text { CV risk assessment/Diagnosis/ } \\
\text { Prognosis }\end{array}$ & Thresholds & Source \\
\hline \multirow[t]{3}{*}{ CT-1 } & $\begin{array}{l}\text { Diagnosis of HHD/LVH } \\
\text { in hypertension }\end{array}$ & $\begin{array}{c}39 \mathrm{fmol} / \mathrm{ml} \\
70 \% \text { sensitivity } \\
75 \% \text { specificity }\end{array}$ & $\begin{array}{l}\text { López } \\
\text { et al. [25] }\end{array}$ \\
\hline & Prognosis of overt HF in hypertension & $\begin{array}{l}152.2 \mathrm{pg} / \mathrm{ml} \\
77 \% \text { sensitivity } \\
85 \% \text { specificity }\end{array}$ & $\begin{array}{l}\text { Bielecka- } \\
\text { Dabrowa } \\
\text { et al. [28] }\end{array}$ \\
\hline & $\begin{array}{l}\text { Prognosis of mortality in chronic HF } \\
\quad \text { (irrespective of etiology) }\end{array}$ & $\begin{array}{l}658 \mathrm{fmol} / \mathrm{ml} \\
57 \% \text { sensitivity } \\
74 \% \text { specificity }\end{array}$ & $\begin{array}{l}\text { Tsutamoto } \\
\text { et al. [30] }\end{array}$ \\
\hline Leptin & $\mathrm{CHD}$ risk assessment & N/A & $\begin{array}{c}\text { Shanker } \\
\text { et al. [51] } \\
\text { Zeng et al. } \\
\quad[41]\end{array}$ \\
\hline \multirow[t]{3}{*}{ Adiponectin } & CHD risk assessment & N/A & $\begin{array}{l}\text { Shanker et } \\
\text { al. [51] }\end{array}$ \\
\hline & Prognosis of CHD & N/A & $\begin{array}{l}\text { Cavusoglu } \\
\text { et al. [65] }\end{array}$ \\
\hline & Prognosis of mortality in chronic HF & $\begin{array}{c}11.6 \mathrm{mg} / \mathrm{l} \\
\mathrm{HR}=3.23(1.11-9.69), p=0.032\end{array}$ & $\begin{array}{l}\text { Kistorp } \\
\text { et al. [64] }\end{array}$ \\
\hline \multirow[t]{3}{*}{ Resistin } & $\begin{array}{l}\text { Prediction of } \mathrm{HF} \text { risk in non-CHD } \\
\text { community dwelling-individuals }\end{array}$ & $\begin{array}{ccc}1.2-10.9 \mathrm{ng} / \mathrm{ml} & 11-14.9 \mathrm{ng} / \mathrm{ml} & 15-110 \mathrm{ng} / \mathrm{ml} \\
\mathrm{HR}=1 & \mathrm{HR}=2.87 & \mathrm{HR}=5.2 \\
& (0.57-14.52) & (1.08-25.13) \\
\end{array}$ & $\begin{array}{l}\text { Frankel } \\
\text { et al. [86] }\end{array}$ \\
\hline & $\begin{array}{l}\text { Prognosis of multivessel CHD (major } \\
\text { cardiac and cerebrovascular events) }\end{array}$ & $\begin{array}{c}17.3 \mathrm{ng} / \mathrm{ml} \\
\mathrm{OR}=13.5(95 \% \mathrm{Cl}: 2.3-80.3) \\
\text { Area under } \mathrm{ROC} \text { curve }=0.75\end{array}$ & $\begin{array}{l}\text { Kręcki } \\
\text { et al. [69] }\end{array}$ \\
\hline & Diagnosis of AMI & $\begin{array}{l}\text { Median }\left(25^{\text {th }}-75^{\text {th }} \text { percentile) levels }\right. \\
\text { at peak }(>12 \mathrm{~h} \text { after pain onset): } \\
5.74 \mathrm{ng} / \mathrm{ml}(438-7.51) \\
\text { Cut-off not available }\end{array}$ & $\begin{array}{l}\text { Lubos } \\
\text { et al. [90] }\end{array}$ \\
\hline \multirow[t]{3}{*}{ Galectin-3 } & $\begin{array}{l}\text { Prognosis of patients with chronic } \\
\text { heart failure (already FDA validated) }\end{array}$ & $\begin{array}{c}\text { Low-risk }<17.8 \mathrm{ng} / \mathrm{ml} \\
\text { Intermediate risk: } 17.8-25.9 \mathrm{ng} / \mathrm{ml} \\
\text { High-risk: }>25.9 \mathrm{ng} / \mathrm{ml}\end{array}$ & $\begin{array}{l}\text { FDA } 510(k) \\
\text { Summary } \\
2010\end{array}$ \\
\hline & $\begin{array}{c}\text { Risk stratification/prognosis in acute } \\
\text { HF (recommended by ACCF/AHA } \\
\text { guidelines) }\end{array}$ & $17.8 \mathrm{ng} / \mathrm{ml}$ & $\begin{array}{l}\text { Peacock } \\
\text { et al. [110] }\end{array}$ \\
\hline & Prediction of incident $\mathrm{HF}$ & N/A & $\begin{array}{l}\text { Jagodzinski } \\
\text { et al. [104] }\end{array}$ \\
\hline
\end{tabular}

ACCF/AHA - American College of Cardiology Foundation/American Heart Association, AMI - acute myocardial infarction, CHD - coronary heart disease, FDA - Food and Drug Administration, HF - heart failure, HHD - hypertensive heart disease, HR - hazard ratio, OR - odds ratio, $R O C$ - receiver operating characteristic, N/A - not available, $L \mathrm{VH}$ - left ventricular hypertrophy.

\section{Adipo(cyto)kines}

Adipocytokines (adipokines) are adipose-derived proteins (hormones and cytokines) produced by the adipose tissue that perform major functions concerning energy expenditure and metabolism, bone mass regulation, insulin sensitivity/resistance, inflammation and cardiovascular function [33, 34]. Recent research has focused on the role of adipocytokines in CV homeostasis.

\section{Leptin}

Leptin is a pleiotropic adipokine, a 167 amino-acid peptide secreted by adipocytes, and a member of the IL-6 family. It is the main an- orexigenic hormone, regulating lipid and glucose metabolism, bone metabolism, immune function and the cardiovascular system [35, 36]. Leptin has recently emerged as a novel and potential risk factor for CVD, being one of the key elements that connects it with obesity.

\section{Pathophysiology and experimental studies}

Obese-associated hyperleptinemia has deleterious vascular effects [35]. By acting on the sympathetic nervous system (SNS), chronic leptin signaling impairs endothelium-dependent vasorelaxation and favors an increased blood pressure response to angiotensin II in murine models [37]. Hyperleptin- 


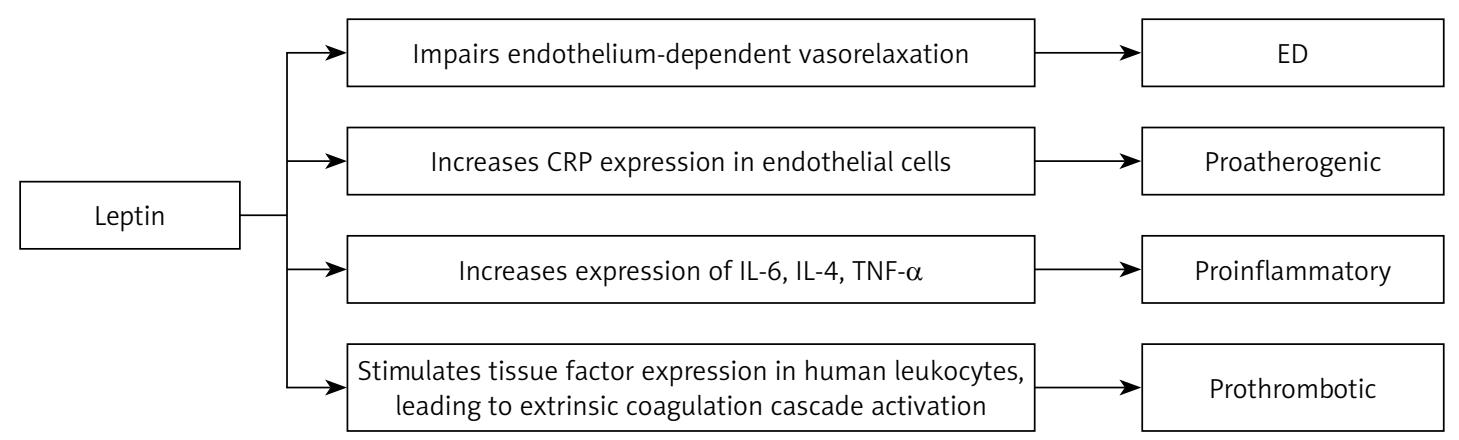

Figure 2. Schematic representation of actions of leptin

ED - endothelial dysfunction, IL-6-interleukin 6, IL-4-interleukin 4, TNF- $\alpha$-tumor necrosis factor $\alpha$.

emia also has proinflammatory [38], proatherogenic [36] and prothrombotic effects [39], thus promoting ED. The pathophysiology of deleterious actions of leptin is presented in Figure 2.

\section{Clinical studies}

In a case-control study performed by Karthick et al. [40], patients with non-thrombolysed AMI had significantly higher levels of leptin [40]. Moreover, in a meta-analysis performed by Zeng et al. [41], high leptin levels were significantly associated with an increase in CHD (including myocardial infarction) $(O R=1.90)$ and stroke risk $(O R=2.14)$ [41]. In support of these findings, hyperleptinemia positively and independently correlated with increased coagulation activity (high circulating levels of coagulation factor VIII, fibrin D-dimer, fibrinogen and von Willebrand factor) in a study performed by Wannamethee et al. [42]. However, the numerous discrepant results in the literature are not to be disregarded, and the following question arises: is the effect of hyperleptinemia on CVD exaggerated? The results were adjusted for age, blood pressure and body mass index (BMI) in all the studies included in the above meta-analysis, but there are other possible confounders that should be taken into consideration. One of them is inflammation, and CRP is an important link between obesity and CVD [43].

Hyperleptinemia is also an independent predictor of $\mathrm{HF}$ in older men without pre-existing CHD, after adjustment for BMI [44]. However, in overweight or obese men with pre-existing CHD, leptin seems to have no additional significant effect, as probably obesity-triggered increased cardiac workload is enough to increase HF risk [45]. Despite high levels in HF, leptin is not a reliable marker as it is highly dependent on body fat: normal/low leptin levels may be encountered in $\mathrm{HF}$ patients with cachexia [45].

\section{Controversies}

There are also studies that have reported paradoxical results regarding the relationship between leptin and CVD risk. In the NAMIS study, low leptin levels 7 days after the onset of an AMI were associated with poor outcome defined as higher risk for adverse cardiovascular events and poor survival [46]. Also, Scholze et al. [47] provided proof that low leptin levels are in fact an independent predictor of all-cause death in hemodialysis patients, with the most frequent cause being CVD [47].

Such contradictory findings are reminiscent of the concept of the "obesity paradox" or "reverse epidemiology": although a high body mass is a conventional risk factor for CVD in apparently healthy individuals, there seems to be a reversal of the relationship between overnutrition and long-term outcome in high-risk patients (chronic kidney disease and/or with already established CHD or HF), where, paradoxically, overnutrition has a protective effect against mortality $[48,49]$. The concept may apply to hyperleptinemia as well, as leptin is a reflection of body fat [33].

\section{Leptin vs. standardly used biomarkers/ other novel potential biomarkers}

In a large prospective population-based study of 6502 participants with a mean follow-up of 11.4 years, leptin did not correlate with incident ischemic heart disease or stroke, after adjustment for sex, age, blood pressure, lipid profile, smoking, comorbidities such as hypertension and diabetes, $\mathrm{BMI}$, insulin resistance parameters, eGFR and CRP. However, CRP remained an independent predictor of ischemic heart disease (fatal and non-fatal) after adjustment for all the above variables and also for leptin and adiponectin [43]. It seems that the association between leptin and CVD is mediated by inflammation/CRP; indeed, leptin and CRP levels seem to correlate and leptin is able to directly regulate CRP synthesis [50]. However, despite the power of leptin alone being limited, it may be useful in conjunction with other biomarkers: the association between leptin, adiponectin and traditional CV risk performed significantly better in predicting CHD when compared to a model that included only the conventional risk factors, with 
maximum reclassification in the intermediate risk group [51].

Overall, these data do not yet support the use of leptin as a biomarker in clinical practice for assessing the risk of CHD. Leptin levels should be interpreted with caution, according to the underlying condition.

\section{Adiponectin}

Adiponectin is a 244 amino acid adipokine, part of the collagen superfamily. The most abundant form in the plasma is the high molecular weight (HMW) adiponectin, the most stable and with the longest half-life [33, 52].

\section{Pathophysiology and experimental studies}

Adiponectin improves insulin sensitivity [53] and fatty acid oxidation [52] and inhibits vascular inflammation [54]. Adiponectin also protects against ED by increasing endothelial nitric oxide synthase (eNOS) activity and by promoting angiogenesis and endothelial cell repair $[52,55,56]$ (Figure 3).

In addition, it inhibits atherogenesis and also has antithrombotic effects $[52,57]$.

\section{Clinical studies}

In a longitudinal population-based cohort study, baseline adiponectin levels were negatively and independently associated with the development of CHD in a 10-year follow-up [58]. Moreover, Wang et al. [59] showed that adiponectin concentration inversely correlates with the severity of coronary artery disease assessed through the Gensini score. In their study, the HMW isoform of adiponectin showed a stronger correlation with the severity of coronary artery disease than total adiponectin did, pointing to the utility of $\mathrm{HMW}$ adiponectin as a potential biomarker for detect- ing the risk of $\mathrm{CHD}$ [59]. Also in type 2 diabetes mellitus (DM) patients, the C1q-adiponectin/total adiponectin ratio is a significant independent predictor of the atherosclerosis score with $72.2 \%$ sensitivity and a positive predictive value of $78.8 \%$. The above relationship could be explained by the anti-atherogenic actions of adiponectin: binding of adiponectin to complement fraction $\mathrm{C} 1 \mathrm{q}$ protects against the $\mathrm{C} 1 \mathrm{q}$-induced inflammatory process in systemic atherosclerosis [60].

Adiponectin may protect against hypertension onset: in a systematic review and meta-analysis performed by Kim et al. [61], adiponectin levels were lower in patients with hypertension than in controls. Also, the risk of developing hypertension decreased with the increase of adiponectin levels.

\section{Controversies}

High adiponectin levels are encountered in $\mathrm{HF}$, where adiponectin increases with left ventricular dysfunction progression. Adiponectin is directly correlated with BNP and NT-proBNP and also with TNF- $\alpha$ : adiponectin may rise in congestive $\mathrm{HF}$ to mitigate the actions of TNF- $\alpha$. Also, HF patients with higher adiponectin levels have a significantly higher mortality risk [62-64]. Thus, adiponectin could be considered in the future as a marker of HF severity and also a predictor of mortality.

Also, adiponectin in the upper quartile in CHD patients is associated with a higher risk of recurrent adverse events [51]. High adiponectin levels are an independent predictor of all-cause and cardiac mortality in patients undergoing coronary angiography for stable angina or ACS [65], in patients with carotid atherosclerosis undergoing carotid endarterectomy [66] and in elderly patients $(\geq 65$ years) [67]. Also, despite an increase 3 months after coronary artery bypass grafting (CABG) in severe $\mathrm{CHD}$ patients, adiponectin directly correlated with markers of ED [68]. It may be speculated that

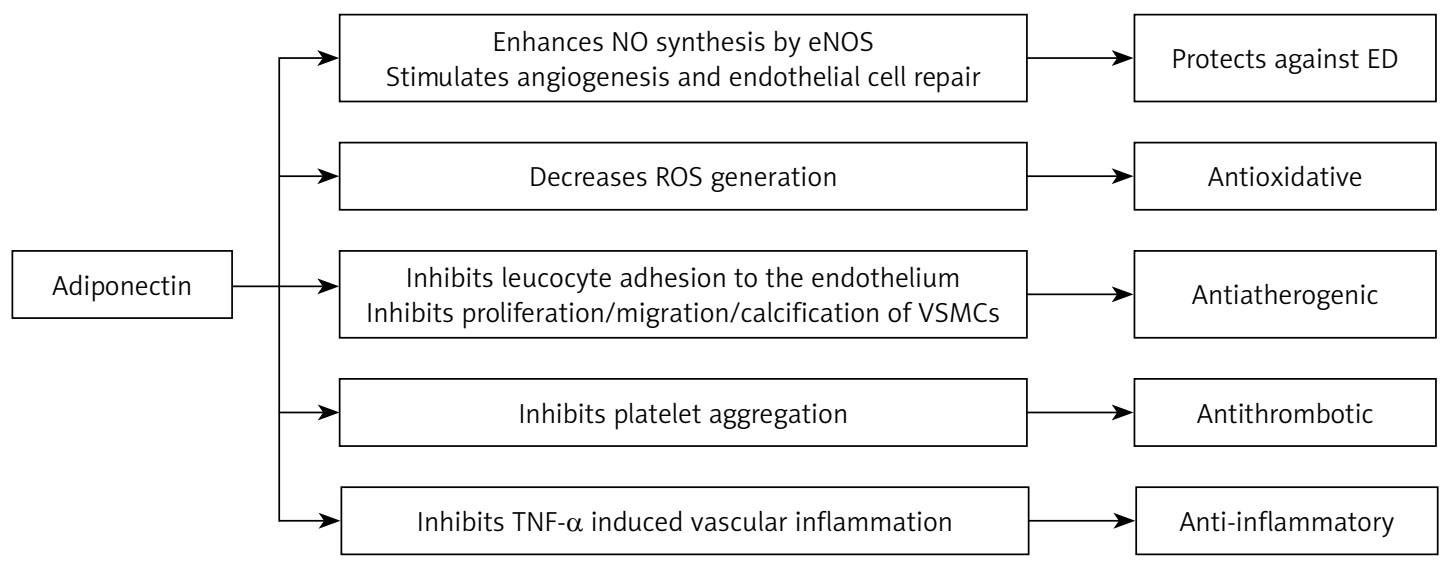

Figure 3. Schematic representation of adiponectin actions

ED - endothelial dysfunction, TNF- $\alpha$-tumor necrosis factor $\alpha, V S M C S$ - vascular smooth muscle cells, eNOS - endothelial nitric oxide synthase, $N O$ - nitric oxide, $R O S$ - reactive oxygen species. 
adiponectin increases as a compensatory mechanism to counteract ED that occurs after CABG. Other authors observed a decrease in adiponectin concentration 12 months after CABG together with a significant improvement of ischemic and HF symptoms [69]. BNP is a strong predictor of adiponectin levels and is associated with adiponectin release from the adipose tissue [70]. Also, high adiponectin levels may be a reflection of adiponectin resistance at the receptor level [69]. This may partially explain why adiponectin predicts negative outcomes in subjects with advanced CVD and also why adiponectin declines as improvement of cardiovascular function occurs after CABG.

Therefore, the interpretation of adiponectin concentration should be made according to underlying CVD severity, as it has different predictive implications (the "adiponectin paradox") [67]: in disease-free subjects, high adiponectin is a marker of low risk for acute or chronic CHD, while in patients with established $\mathrm{CHD} / \mathrm{HF}$, high adiponectin levels seem to be independent predictors of future adverse events [71].

\section{Adiponectin vs. standardly used biomarkers}

In order to evaluate the prognostic power of adiponectin in patients with established CHD, Ang et al. [72] compared adiponectin to BNP with regards to predicting a future adverse outcome (all-cause death, readmission for ACS or congestive HF) in patients with ACS: an increase in adiponectin following admission for ACS better predicted adverse outcome than single determinations at baseline and 7 weeks, but this relationship was lost after adjustment for BNP. Therefore, BNP performs better than adiponectin for prognosis of adverse events in ACS [72].

As mentioned above, adiponectin is independently associated with NP and parallels the evolution of HF [62]. Adiponectin is a predictor of mortality in HF, independently of NP (Table IV) [64]. Subsequently, the hypothesis that adiponectin could be used in conjunction with NP to improve mortality risk assessment in $\mathrm{HF}$ is to be verified.

\section{Resistin}

Resistin is a proinflammatory cytokine, a member of the adipokines, predominantly produced by macrophages but also released from the adipose tissue [73]. Resistin is involved in the pathogenesis of insulin resistance ("resists" insulin actions) and is also thought to be a contributory factor in CVD development [73].

\section{Pathophysiology and experimental studies}

Firstly, high levels of resistin are associated with insulin resistance and diabetes: resistin upregulates the suppressor of cytokine signaling-3
(SOCS-3) pathway that leads to downregulation of insulin receptor expression and also inhibits phosphatidyl inositol 3-kinase activation that mediates insulin metabolic functions [53]. Secondly, resistin promotes ED, atherogenesis and atherothrombosis, having direct effects on the vessels: (1) resistin down-regulates eNOS gene expression, leading to low nitric oxide levels with reduced vasorelaxation function [73], (2) resistin increases foam cell formation [74] and also proliferation and migration of VSMCs $[75,76],(3)$ resistin upregulates the expression of genes associated with atherothrombosis [77]. Vascular thrombosis manifested as increased platelet reactivity and adherence to the endothelium and ED are the main triggers of CVD [78]. Finally, resistin also upregulates TNF- $\alpha$ expression and activates the NF- $\kappa$ B proinflammatory signaling pathway in the myocardium, leading to cardiac inflammation and fibrosis [79]. These findings led to the investigation of resistin as a possible marker and therapeutic target in CVD (Figure 4).

\section{Clinical studies}

In prospective studies, high resistin significantly increases the risk for all CVD, chronic CHD [80] and acute coronary syndrome, independently of other CV risk factors, including markers of inflammation (IL-6 and CRP) [81]. A resistin concentration equal to or above $17.3 \mathrm{ng} / \mathrm{ml}$ is associated with a 13-fold increase in the risk of major cardiac and cerebrovascular events in patients with multivessel coronary disease (Table IV) [82]. Resistin levels also rise $24 \mathrm{~h}$ after CABG as a marker of ischemia-reperfusion injury and are correlated with oxidative stress [83]. However, resistin levels do not seem to change after 12 months of medical treatment or CABG in these patients and thus may not be helpful for follow-up after therapeutic intervention [69]. Also, adding resistin to traditional CV risk factors significantly improves the risk assessment for ischemic stroke [84].

Nevertheless, resistin is a strong independent predictor of incident HF in community-dwelling older individuals and is also correlated with NYHA functional class in prospective studies. Whether resistin has a negative direct impact on the myocardium or it is merely a reflection of the vascular inflammatory process, it can be proposed as a biomarker for HF risk assessment and stratification $[45,85,86]$.

Moreover, a meta-analysis performed by Fontana et al. [87] regarding the influence of resistin on mortality in high-risk patients (patients with CHD, myocardial infarction, ischemic stroke, type $2 \mathrm{DM}$, end-stage renal disease) showed that resistin significantly increased the risk for all-cause mortality, with a hazard ratio (HR) of 1.24 for 1 standard deviation increment in resistin levels. In the same meta-analysis, the effect of resistin 


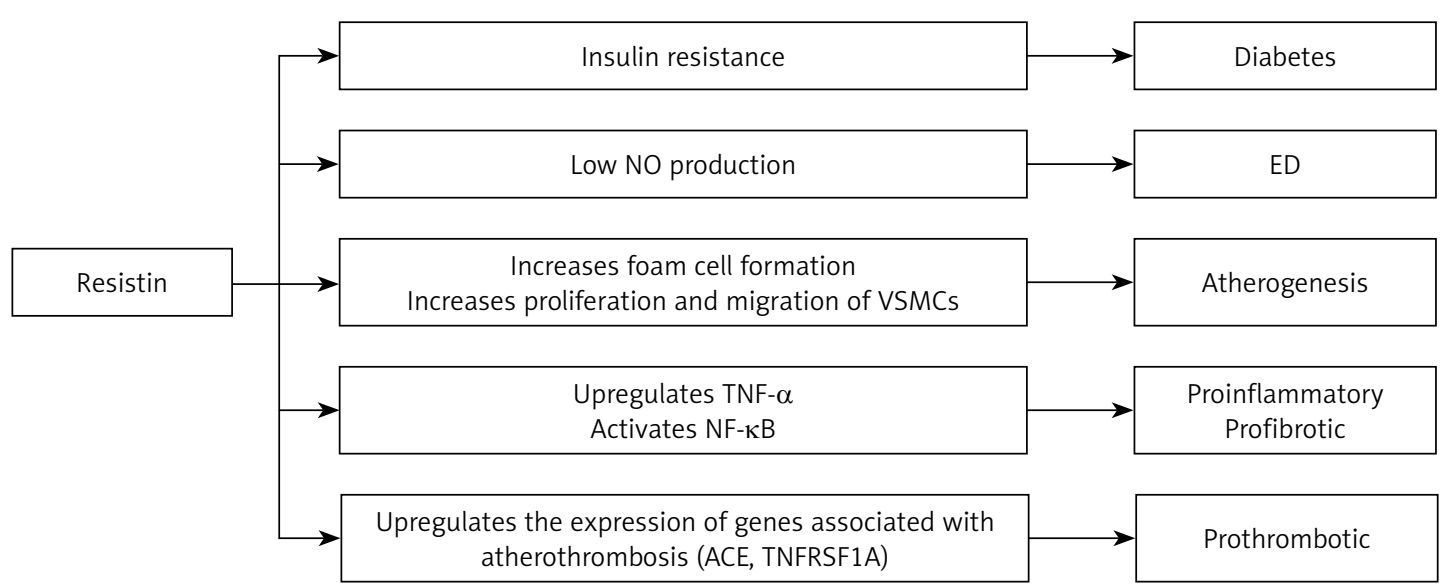

Figure 4. Schematic representations of resistin actions

$E D$ - endothelial dysfunction, NO - nitric oxide, NF- $\kappa B$ - nuclear factor $\kappa B, A C E$ - angiotensin converting enzyme, TNFRSF1At tumor necrosis factor receptor superfamily member $1 A$, TNF- $\alpha$-tumor necrosis factor $\alpha, V S M C s-v a s c u l a r$ smooth muscle cells.

on cardiovascular mortality was however neutral $(\mathrm{HR}=1.05$ for 1 standard deviation increase in resistin levels) [87].

\section{Controversies}

In the prospective study of Zhang et al. [88], resistin did not provide prognostic information beyond traditional risk factors regarding the development of $\mathrm{HF}$ in $\mathrm{CHD}$ patients. Therefore, resistin may be proposed as a biomarker for HF in non-CHD individuals.

\section{Resistin vs. standardly used biomarkers}

Although resistin significantly correlates with CRP and BNP levels, resistin is a predictor of HF in the community, independently of these biomarkers, and the predictive power is maintained after the exclusion of CHD individuals. The HRs for incident $\mathrm{HF}$ in the second and third tertile of resistin after adjusting for various cardiovascular risk factors, CRP and BNP are presented in Table IV [86].

Resistin levels correlate with troponin $24 \mathrm{~h}$ after CABG, reflecting myocardial injury [83]. Resistin levels are also significantly increased in $\mathrm{AMI}$ and unstable and stable angina patients, with resistin being significantly higher in AMI than in unstable/ stable angina. Resistin correlates with myocardial injury enzymes, troponin I and CRP in AMI, but not in unstable/stable angina patients [89]. Resistin rises 3-6 $\mathrm{h}$ after chest pain onset and peaks $12 \mathrm{~h}$ after chest pain onset (Table IV) [90]. Thus, resistin could become a biomarker for AMI.

Overall, increasing clinical evidence supports the use of resistin as a cardiovascular marker for risk stratification and prognostic in CHD and as a predictor of HF in community-dwelling individuals. Clinical studies that evaluate the prognostic power of resistin in comparison to that of classical biomarkers are needed.

\section{Galectin-3}

Galectin-3 is a member of the lectin family, encoded by the LGALS3 gene located on chromosome 14. It is expressed predominantly by macrophages and plays an important role in the pathophysiology of immunity/inflammation related diseases (cancer, metabolic diseases). Galectin-3 is a marker of tissue fibrosis, including cardiovascular fibrosis, and also of atherosclerosis. Consequently, galectin-3 has emerged as a new biomarker for CV disease, especially HF but not only [91, 92].

\section{Pathophysiology and experimental studies}

Galectin-3 is one of the key links between inflammation and fibrosis at the cardiovascular level $[91,92]$. It regulates chronic inflammation within the vessels by promoting osteogenic differentiation of VSMCS, leading to macrocalcifications in the atherosclerotic plaques [92, 93]. Galectin-3 is a profibrotic agent by itself and also mediates aldosterone-induced cardiac, vascular and renal fibrosis $[91,94]$. High galectin-3 levels in the myocardium stimulate excessive collagen production [95] and are correlated with abundant macrophages, increased fibroblast activity and increased accumulation of extracellular matrix [96]. Galectin-3 levels also show a later peak in non-infarcted, remodeling areas in rat models of myocardial infarction [97]. Thus, galectin-3 is a marker of cardiac fibrosis and remodeling (Figure 5).

\section{Clinical studies}

\section{Chronic heart failure}

In the above-mentioned context, it is not surprising that galectin-3 is a biomarker for chron- 


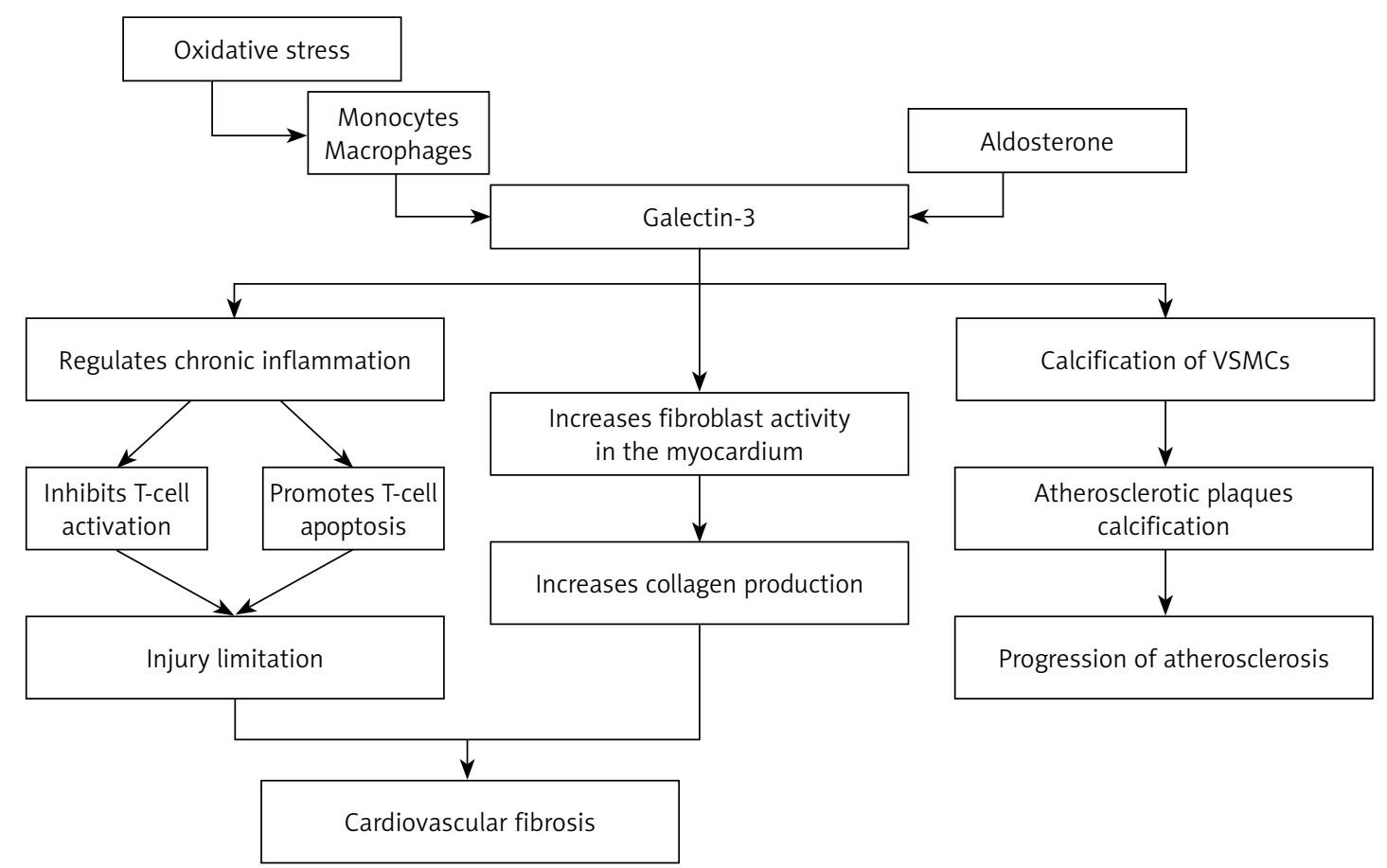

Figure 5. Schematic representation of galectin-3 actions VSMCS - vascular smooth muscle cells.

ic HF prognosis [91]. Although galectin-3 lost its predictive power for future adverse outcome in chronic HF after adjusting for NT-proBNP in some studies $[98,99]$, it remains a significant independent predictor of all-cause mortality [14], adverse CV events (including cardiac death) and left ventricular remodeling in patients with left ventricular systolic dysfunction in most trials [14, 100, 101]. It is also a significant independent predictor of all-cause death and hospitalization in patients with HF with preserved ejection fraction [102].

\section{Acute heart failure}

Galectin-3 is also a promising biomarker in acute heart failure (AHF). In a pooled analysis from 3 cohorts of patients admitted to hospital for AHF (AHF patients from COACH, PRIDE and UMD $\mathrm{H}-23258$ trials), galectin-3 was a significant predictor of rehospitalization for $\mathrm{HF}$ at 30, 60, 90 and 120 days, independently of New York Heart Association (NYHA) functional class, renal function, left ventricular ejection fraction and BNP [103]. It was also a significant independent predictor of the composite outcome all-cause mortality and HF rehospitalization in PRIDE and UMD H-23258 cohorts [103].

\section{Non-heart failure subjects}

Galectin-3 may also be used as a biomarker for $\mathrm{CV}$ adverse outcome in non-HF individuals. Interestingly, galectin-3 significantly and independently predicted incident HF and all-cause mortality in the largest population-based cohort in which the relationship between galectin-3, HF and mortality risk was assessed (FINRISK 1997 cohort) [104].

\section{Controversies}

Renal function seems to be an important confounder when assessing the prognostic value of galectin-3: the association between high levels of galectin-3 and prognosis of HF was lost after adjusting for eGFR in some studies [105, 106]. Galectin-3 levels strongly correlate with eGFR (inverse relationship) in HF patients [14]. Therefore, the interpretation of galectin-3 should take into consideration renal function.

\section{Guidelines}

The use of the galectin-3 assay is currently approved by the FDA for the prognosis of chronic HF together with clinical assessment [91]. The 2013 American College of Cardiology Foundation/ American Heart Association (ACCF/AHA) Guideline for management of HF also states that galectin-3 may be considered an additional biomarker for both chronic (class IIb recommendation, level of evidence B) and acute HF (class Ilb recommendation, level of evidence $A$ ) improved risk stratification [8]. Whether galectin-3 may be useful in predicting $\mathrm{CV}$ risk in non-HF patients still needs to be established.

\section{Galectin-3 vs. standardly used biomarkers}

Galectin-3 is a prognostic marker for all-cause mortality and rehospitalization in chronic HF, inde- 
pendently of NP $[8,14,100,101]$. Also, galectin-3 adds prognostic information to that provided by NT-proBNP in HF patients with NT-proBNP above the median (Table IV) [107].

In a recent head-to-head comparison of ST-2 and galectin-3 for risk stratification in chronic $\mathrm{HF}$ performed by Bayes-Genis et al. [108], ST-2 proved superior: ST-2 brought a significant increase in the predictive power of a risk model for HF composed of 11 classical risk factors and NT-proBNP, while the contribution of galectin-3 was negligible - hence the observation that galectin-3 may be more useful in early stages of HF and the need for trials that investigate the predictive utility of galectin-3 according to HF stages [108].

Despite NT-proBNP being more sensitive than galectin-3 in diagnosing AHF, galectin- 3 was a better predictor for 60-day mortality and for the composite end-point death and recurrent HF within 60 days in AHF patients. The combination of galectin-3 and NT-proBNP best predicts death/recurrent HF in AHF [109].

Peacock [110] developed an algorithm for the emergency department recommending managing HF presentations (emergency department treatment and discharge, observation unit admission with 24-hour re-evaluation or immediate hospitalization) according to BNP and galectin-3 levels. The algorithm has not yet been validated. Galectin-3 in combination with NT-proBNP may be useful in short-term risk reclassification of patients with AHF and could help decision-making in order to better identify candidates for admission to intensive care units and candidates for discharge.

\section{The multimarker approach}

Cardiovascular disease have multiple pathophysiological backgrounds: HF is a result of inflammation, myocardial remodeling, cardiomyocyte injury

Table V. Combinations of biomarkers that proved superior to single biomarker assessment and proposed multimarker associations to assess in future trials

\begin{tabular}{|c|c|c|c|c|}
\hline $\begin{array}{l}\text { Proposed } \\
\text { association } \\
\text { of biomarkers }\end{array}$ & $\begin{array}{c}\text { Type of } \\
\text { information } \\
\text { and indication }\end{array}$ & Advantages & $\begin{array}{l}\text { Pitfalls/confounders that } \\
\text { may influence the power } \\
\text { of prediction/risk strati- } \\
\text { fication }\end{array}$ & Source \\
\hline $\begin{array}{l}\text { CT-1 + } \\
\text { NT-proBNP }\end{array}$ & $\begin{array}{l}\text { Diagnosis } \\
\text { of HF in } \\
\text { hypertension }\end{array}$ & $\begin{array}{l}\text { Increases sensitivity for } \\
\text { diagnosing HF (78\%) compared } \\
\text { to NT-proBNP alone (72\%) and } \\
\text { slightly improves AUC (from } 0.818 \\
\text { for NT-proBNP alone to } 0.854 \text { ) }\end{array}$ & $\begin{array}{l}\text { Metabolic syndrome (also } \\
\text { increased levels of CT-1) } \\
\text { Chronic kidney disease } \\
\text { (increases NT-proBNP) }\end{array}$ & $\begin{array}{l}\text { Lopez } \\
\text { et al. [29] }\end{array}$ \\
\hline $\mathrm{CT}-1+\mathrm{BNP}$ & $\begin{array}{l}\text { Prognosis of } \\
\text { mortality in } \\
\text { chronic HF }\end{array}$ & $\begin{array}{c}\mathrm{HR}=2.48 \text { for } \mathrm{BNP}>170 \mathrm{pg} / \mathrm{ml} \\
+\mathrm{CT}-1>658 \mathrm{fmol} / \mathrm{ml} \text { vs. BNP }> \\
170 \mathrm{pg} / \mathrm{ml}+\mathrm{CT}-1<658 \mathrm{fmol} / \mathrm{ml} \\
(p=0.01)\end{array}$ & $\begin{array}{l}\text { Metabolic syndrome (also } \\
\text { increased levels of CT-1) } \\
\text { Chronic kidney disease } \\
\text { (increases NT-proBNP) }\end{array}$ & $\begin{array}{l}\text { Tsutamoto } \\
\text { et al. [30] }\end{array}$ \\
\hline $\begin{array}{l}\text { Galectin-3 + } \\
\text { NT-proBNP }\end{array}$ & $\begin{array}{l}\text { Prognosis of } \\
\text { mortality in } \\
\text { chronic HF }\end{array}$ & $\begin{array}{l}\mathrm{HR}=1.84 \text { for NT-proBNP }>932 \\
\mathrm{pg} / \mathrm{ml}+\text { galectin- } 3>16.2 \mathrm{ng} / \mathrm{ml}\end{array}$ & $\begin{array}{l}\text { Chronic kidney disease } \\
\text { (both correlate with } \\
\text { kidney function) }\end{array}$ & $\begin{array}{c}\text { Anand } \\
\text { et al. [107] } \\
\text { (Val-HeFT trial) }\end{array}$ \\
\hline $\begin{array}{l}\text { Galectin-3 + } \\
\text { NT-proBNP }\end{array}$ & $\begin{array}{l}\text { Prognosis } \\
\text { of death/ } \\
\text { recurrent HF } \\
\text { in AHF }\end{array}$ & $\begin{array}{c}\text { Galectin-3 }>9.42 \mathrm{ng} / \mathrm{ml}+ \\
\text { NT-proBNP }>5562 \mathrm{pg} / \mathrm{ml} \text { was } \\
\text { associated with significantly } \\
\text { higher risk of mortality/recurrent } \\
\text { heart failure than either marker } \\
\text { alone }\end{array}$ & $\begin{array}{l}\text { Chronic kidney disease } \\
\text { (both correlate with } \\
\text { kidney function) }\end{array}$ & $\begin{array}{l}\text { Van Kimmenade } \\
\quad \text { et al. [109] }\end{array}$ \\
\hline \multicolumn{5}{|c|}{ Potential multimarker assessments to consider in future clinical trials } \\
\hline \multicolumn{5}{|c|}{$\begin{array}{l}\text { Chronic HF prediction and prognosis } \\
\text { Resistin + BNP/NT-proBNP + CT-1 }\end{array}$} \\
\hline \multicolumn{5}{|c|}{$\begin{array}{l}\text { Chronic HF prognosis } \\
\text { Adiponectin + BNP/NT-proBNP + CT-1 }\end{array}$} \\
\hline \multicolumn{5}{|c|}{$\begin{array}{l}\text { CHD risk stratification } \\
\text { Resistin + BNP/NT-proBNP }\end{array}$} \\
\hline \multicolumn{5}{|c|}{$\begin{array}{l}\text { Diagnosis of ACS } \\
\text { Resistin + myocardial enzymes + troponin }\end{array}$} \\
\hline $\begin{array}{l}\text { CHD risk asses } \\
\text { Leptin + adipor }\end{array}$ & $\begin{array}{l}\text { nent } \\
\text { ctin }+ \text { CRP }\end{array}$ & & & \\
\hline
\end{tabular}

ACS - acute coronary syndrome, AHF - acute heart failure, AUC - area under the curve, CHD - coronary heart disease, HF - heart failure, $H R$ - hazard ratio. 
and neurohormonal activation, while $\mathrm{CHD}$ is the result of vascular inflammation, atherosclerosis, thrombosis and ED. Therefore, a multibiomarker assessment could provide a global assessment of the disease, thus increasing the predictive and prognosis accuracy. Also, despite its limited utility when used alone, a biomarker may still be helpful when integrated into a biomarker panel [5]. In this regard, Ky et al. [111] investigated the utility of a panel consisting of 8 biomarkers reflecting different biological processes as a prognostic tool in chronic HF. Established biomarkers such as troponin I, BNP, ST-2, CRP, creatinine, and uric acid were included together with markers of oxidative stress and vascular growth and remodeling. The multimarker score significantly reclassified $24 \%$ of patients as higher risk when added to clinical risk scores.

The difficulty consists in identifying those multibiomarker panels that perform best for the minimum cost and are easy to assay. Also, the optimal biomarker panel should best guide therapeutic management [112]. As numerous potential biomarkers have been discovered, now the great challenge is to identify the optimal multibiomarker test.

Most of the above-mentioned molecules proved to be significant predictors of CVD and associated mortality, alone and in conjunction with traditional biomarkers. The combinations of biomarkers that are promising for further analysis in clinical trials are presented in Table V.

\section{Conclusions}

Combining various new risk markers could help improve risk-based intervention and achieve the optimal therapeutic approach, as traditional CV risk factors are in many cases not able to provide a clear assessment of risk strata. Nevertheless, CT-1 is a promising biomarker for assessing risk in hypertensive patients. It would allow the identification of patients at high risk for developing $\mathrm{HF}$, and it could also be a useful tool for assessing treatment outcome. High leptin, low adiponectin and high resistin levels are biomarkers of vascular inflammation, dysfunction, atherosclerosis, and increased stiffness and could be used to predict CV disease and outcome, according to the underlying CV state. Galectin-3 is already recommended for establishing prognosis in both acute and chronic HF patients. Although clinical trials have also shown promising results for galectin-3 as an independent prognostic factor for assessing CV risk in non-HF patients, its best predictive value seems to be in high-risk patients.

Most studies are in favor of using the above-mentioned molecules as new biomarkers for CVD and mortality. The practical use of a multi-biomarker evaluation in conjunction with risk score models already available could bring valuable information regarding disease or risk prognosis, especially as these new biomarkers promise to bring a significant increase in the predictive power of already established biomarkers (e.g. BNP) and/or clinical factor algorithms.

\section{Acknowledgments}

This work received financial support through the "CERO - CAREER PROFILE: Romanian researchers", contract no. POSDRU/159/1.5/S/135760, a project co-financed by the European Social Fund Operational Programme Human Resources Development 2007-2013.

Simona Hogas, Stefana C. Bilha - These authors contributed equally to this work.

\section{Conflict of interest}

The authors declare no conflict of interest.

\section{References}

1. Dorobantu M, Tautu OF, Darabont F, et al. Objectives and methodology of Romanian SEPHAR II Survey. Project for comparing the prevalence and control of cardiovascular risk factors in two East-European countries: Romania and Poland. Arch Med Sci 2015; 11: 715-23.

2. Mendis S, Puska P, Norrving B. Global atlas on cardiovascular disease prevention and control. World Health Organization, Geneva 2011. Available at http://www. who.int/cardiovascular_diseases/publications/atlas_ cvd/en/.

3. De Backer GG. New risk markers for cardiovascular prevention. Curr Atheroscler Rep 2014; 16: 427.

4. Gonzalez A, Lopez B, Ravassa S, et al. Cardiotrophin-1 in hypertensive heart disease. Endocrine 2012; 42: 9-17.

5. Sun RR, Lu L, Liu M, et al. Biomarkers and heart disease. Eur Rev Med Pharmacol Sci 2014; 18: 2927-35.

6. Latini R, Masson S. NT-PROBNP: a guide to improve the management of patients with heart failure. JIFCC 2013; 24: 3-4.

7. Battistoni A, Rubattu S, Volpe M. Circulating biomarkers with preventive, diagnostic and prognostic implications in cardiovascular diseases. Int J Cardiol 2012; 157: 160-8.

8. Yancy CW, Jessup M, Bozkurt B, et al. 2013 ACCF/AHA guideline for the management of heart failure: a report of the American College of Cardiology Foundation/ American Heart Association Task Force on Practice Guidelines. J Am Coll Cardiol 2013; 62: e147-239.

9. Raizada A, Bhandari S, Khan MA, et al. Brain type natriuretic peptide (BNP) - a marker of new millenium in diagnosis of congestive heart failure. Ind I Clin Biochem 2007; 22: 4-9.

10. del Val Martin D, Sanmartin Fernandez M, Zamorano Gomez JL. Biomarkers in acute coronary syndrome. IJC Metabolic Endocrine 2015; 8: 20-3.

11. US Food and Drug Administration. Review criteria for assessment of C-reactive protein (CRP), high sensitivity C-reactive protein, and cardiac C-reactive protein (cCRP) assays. 2005. http://www.fda.gov/downloads/ MedicalDevices/DeviceRegulationandGuidance/GuidanceDocuments/ucm071017.pdf

12. Ridker PM. High-sensitivity C-reactive protein: potential adjunct for global risk assessment in the prima- 
ry prevention of cardiovascular disease. Circulation 2001; 103: 1813-8.

13. French D, Wu AHB. Cardiac markers. In: The immunoassay handbook: theory and applications of ligand binding, ELISA and related techniques. Wild D (ed.). Elsevier, Oxford 2013; 828-9.

14. Tang WHW, Shrestha K, Shao Z, et al. Usefulness of plasma galectin-3 levels in systolic heart failure to predict renal insuficiency and survival. Am J Cardiol 2011; 108: 385-90.

15. Kehl DW, Iqbal N, Fard A, et al. Biomarkers in acute myocardial injury. Transl Res 2012; 159: 252-64.

16. Cabaniss CD. Creatine kinase. In: Clinical methods: the history, physical, and laboratory examinations. 3rd ed. Hall WD, Hurst JW, Walker HK (eds.). Butterworths, Boston 1990; 161-3.

17. Pennica D, King KL, Shaw KJ, et al. Expression cloning of cardiotrophin 1, a cytokine that induces cardiac myocyte hypertrophy. Proc Natl Acad Sci USA 1995; 92: 1142-6.

18. Sheng Z, Knowlton K, Chen J, Hoshijima M, Brown JH, Chien KR. Cardiotrophin 1 (CT-1) inhibition of cardiac myocyte apoptosis via a mitogen-activated protein kinase-dependent pathway. Divergence from downstream CT-1 signals for myocardial cell hypertrophy. J Biol Chem 1997; 272: 5783-91.

19. Calabro P, Limongelli G, Riegler L, et al. Novel insights into the role of cardiotrophin-1 in cardiovascular diseases. J Mol Cell Cardiol 2009; 46: 142-8.

20. Takahashi N, Saito Y, Kuwahara K, et al. Hypertrophic responses to cardiotrophin-1 are not mediated by STAT3, but via a MEK5-ERK5 pathway in cultured cardiomyocytes. J Mol Cell Cardiol 2005; 38: 185-92.

21. Konii H, Sato K, Kikuchi S, et al. Stimulatory effects of cardiotrophin-1 on atherosclerosis. Hypertension 2013; 62: 942-50.

22. Ichiki T, Jougasaki $M$, Setoguchi $M$, et al. Cardiotrophin-1 stimulates intercellular adhesion molecule-1 and monocyte chemoattractant protein-1 in human aortic endothelial cells. Am J Physiol Heart Circ Physiol 2008; 294: H750-63.

23. Lopez Andres N, Calvier L, Labat C, et al. Absence of cardiotrophin 1 is associated with decreased age-dependent arterial stiffness and increased longevity in mice. Hypertension 2013; 61: 120-9.

24. Song K, Wang S, Huang B, Luciano A, Srivastava R, Mani A. Plasma cardiotrophin-1 levels are associated with hypertensive heart disease: a meta-analysis. J Clin Hypertens (Greenwich) 2014; 16: 686-92.

25. López B, González A, Lasarte JJ, et al. Is plasma cardiotrophin-1 a marker of hypertensive heart disease? J Hypertens 2005; 23: 625-32.

26. Talwar S, Squire IB, Downie PF, O'Brien RJ, Davies JE, $\mathrm{Ng}$ LL. Elevated circulating cardiotrophin-1 in heart failure: relationship with parameters of left ventricular systolic dysfunction. Clin Sci 2000; 99: 83-8.

27. Celik A, Sahin S, Koc F, et al. Cardiotrophin-1 plasma levels are increased in patients with diastolic heart failure. Med Sci Monit 2012; 18: CR25-31.

28. Bielecka-Dabrowa A, Gluba-Brzozka A, Michalska-Kasiczak M, Misztal M, Rysz J, Banach M. The multi-biomarker approach for heart failure in patients with hypertension. Int J Mol Sci 2015; 16: 10715-33.

29. Lopez B, Gonzalez A, Querejeta R, Barba J, Diez J. Association of plasma cardiotrophin-1 with stage $C$ heart failure in hypertensive patients: potential diagnostic implications. J Hypertens 2009; 27: 418-24.
30. Tsutamoto T, Asai S, Tanaka T, et al. Plasma level of cardiotrophin-1 as a prognostic predictor in patients with chronic heart failure. Eur J Heart Fail 2007; 9: 1032-7.

31. Gonzalez A, Lopez B, Martin-Raymondi D, et al. Usefulness of plasma cardiotrophin-1 in assessment of left ventricular hypertrophy regression in hypertensive patients. J Hypertens 2005; 23: 2297-304.

32. Vespasiani-Gentilucci U, De Vincentis A, Argemi J, et al. Cardiotrophin-1 is not associated with carotid or coronary disease and is inversely associated with obesity in patients undergoing coronary angiography. Arch Med Sci 2013; 9: 635-9.

33. Mattu HS, Randeva HS. Role of adipokines in cardiovascular disease. J Endocrinol 2013; 216: T17-36.

34. Mohiti-Ardekani J, Soleymani-Salehabadi H, Owlia MB, Mohiti A. Relationships between serum adipocyte hormones (adiponectin, leptin, resistin), bone mineral density and bone metabolic markers in osteoporosis patients. J Bone Miner Metab 2014; 32: 400-4.

35. Mantzoros C, Magkos F, Brinkoetter M, et al. Leptin in human physiology and pathophysiology. Am J Physiol Endocrinol Metab 2011; 301: E567-84.

36. Patel S, Reams GP, Spear RM, Freeman RH, Villarreal D. Leptin: linking obesity, the metabolic syndrome, and cardiovascular disease. Curr Hypertens Rep 2008; 10: 131-7.

37. Wang J, Wang H, Luo W, et al. Leptin-induced endothelial dysfunction is mediated by sympathetic nervous system activity. J Am Heart Assoc 2013; 2: e000299.

38. Singh P, Hoffmann M, Wolk R, Shamsuzzaman ASM, Somers VK. Leptin induces C-reactive protein expression in vascular endothelial cells. Arterioscler Thromb Vasc Biol 2007; 27: e302-7.

39. Rafaila S, Ritisa K, Schaeferb K, et al. Leptin induces the expression of functional tissue factor in human neutrophils and peripheral blood mononuclear cells through JAK2-dependent mechanisms and TNFalpha involvement. Thromb Res 2008; 122: 366-75.

40. Karthick R, Nalini D, Manohar G, Malathi R. Obesity, inflammation and acute myocardial infarction - expression of leptin, IL-6 and high-sensitivity-CRP in Chennai based population. Thromb J 2012; 10: 13.

41. Zeng R, Xu CH, Xu YN, Wang YL, Wang M. Association of leptin levels with pathogenetic risk of coronary heart disease and stroke: a meta-analysis. Arq Bras Endocrinol Metab 2014; 58: 817-23.

42. Wannamethee SG, Tchernova J, Whincup P, et al. Plasma leptin: associations with metabolic, inflammatory and haemostatic risk factors for cardiovascular disease. Atherosclerosis 2007; 191: 418-26.

43. Seven E, Husemoen LL, Sehested TS, et al. Adipocytokines, C-reactive protein, and cardiovascular disease: a population-based prospective study. PLoS One 2015; 10: e0128987.

44. Wannamethee SG, Shaper AG, Whincup PH, Lennon L, Sattar N. Obesity and risk of incident heart failure in older men with and without pre-existing coronary heart disease. J Am Coll Cardiol 2011; 58: 1870-7.

45. Yanavitski M, Givertz MM. Novel biomarkers in acute heart failure. Curr Heart Fail Rep 2011; 8: 206-11.

46. Morita Y, Maeda K, Kondo T, et al. Impact of adiponectin and leptin on long-term adverse events in Japanese patients with acute myocardial infarction. Results from the Nagoya Acute Myocardial Infarction Study (NAMIS). Circ J 2013; 77: 2778-85.

47. Scholze A, Rattensperger D, Zidek W, Tepel M. Low serum leptin predicts mortality in patients with chronic kidney disease stage 5. Obesity 2007; 15: 1617-22. 
48. Chrysant SG, Chrysant GS. New insights into the true nature of the obesity paradox and the lower cardiovascular risk. J Am Soc Hypertens 2013; 7: 85-94.

49. Kalantar-Zadeh K, Block G, Humphreys MH, Kopple JD. Reverse epidemiology of cardiovascular risk factors in maintenance dialysis patients. Kidney Int 2003; 63: 793-808.

50. Hribal ML, Fiorentino TV, Sesti G. Role of $C$ reactive protein (CRP) in leptin resistance. Curr Pharm Des 2014; 20: 609-15.

51. Shanker J, Rao VS, Ravindran V, et al. Relationship of adiponectin and leptin to coronary artery disease, classical cardiovascular risk factors and atherothrombotic biomarkers in the IARS cohort. Thromb Haemost 2012; 108: 769-80.

52. Ebrahimi-Mamaeghani M, Mohammadi S, Arefhosseini SR, Fallah P, Bazi Z. Adiponectin as a potential biomarker of vascular disease. Vasc Health Risk Manag 2015; 11: 55-70.

53. Papaetis GS, Papakyriakou P, Panagiotou TN. Central obesity, type 2 diabetes and insulin: exploring a pathway full of thorns. Arch Med Sci 2015; 11: 463-82.

54. Wang Y, Wang X, Lau WB, et al. Adiponectin inhibits tumor necrosis factor-alpha-induced vascular inflammatory response via caveolin-mediated ceramidase recruitment and activation. Circ Res 2014; 114: 792-805

55. Margaritis M, Antonopoulos AS, Digby J, et al. Interactions between vascular wall and perivascular adipose tissue reveal novel roles for adiponectin in the regulation of endothelial nitric oxide synthase function in human vessels. Circulation 2013; 127: 2209-21.

56. Adya R, Tan BK, Chen J, Randeva HS. Protective actions of globular and full-length adiponectin on human endothelial cells: novel insights into adiponectin-induced angiogenesis. J Vasc Res 2012; 49: 534-43.

57. Kato $\mathrm{H}$, Kashiwagi $\mathrm{H}$, Shiraga $\mathrm{M}$, et al. Adiponectin acts as an endogenous antithrombotic factor. Arterioscler Thromb Vasc Biol 2006; 26: 224-30.

58. Frystyk J, Berne C, Berglund L, Jensevik K, Flyvbjerg A, Zethelius B. Serum adiponectin is a predictor of coronary heart disease: a population-based 10-year follow-up study in elderly men. J Clin Endocrinol Metab 2007; 92: 571-6.

59. Wang Y, Zheng A, Yan Y, et al. Association between HMW adiponectin, HMW-total adiponectin ratio and early-onset coronary artery disease in Chinese population. Atherosclerosis 2014; 235: 392-7.

60. Hirata A, Kishida K, Kobayashi H, Nakatsuji H, Funahashi T, Shimomura I. Correlation between serum C1q-adiponectin/total adiponectin ratio and polyvascular lesions detected by vascular ultrasonography in Japanese type 2 diabetics. Metabolism 2013; 62: 376-85.

61. Kim DH, Kim C, Ding EL, Townsend MK, Lipsitz LA. Adiponectin levels and the risk of hypertension: a systematic review and meta-analysis. Hypertension 2013; 62: 27-32.

62. Nakamura T, Funayama H, Kubo N, et al. Association of hyperadiponectinemia with severity of ventricular dysfunction in congestive heart failure. Circ J 2006; 70: 1557-62.

63. Sokhanvar S, Sheykhi M, Mazlomzade S, Taran L, Golmohammadi Z. The relationship between serum adiponectin and prognosis in patients with heart failure. Bratisl Lek Listy 2013; 114: 455-9.

64. Kistorp C, Faber J, Galatius S, et al. Plasma adiponectin, body mass index, and mortality in patients with chronic heart failure. Circulation 2005; 112: 1756-62.
65. Cavusoglu E, Ruwende C, Chopra V, et al. Adiponectin is an independent predictor of all-cause mortality, cardiac mortality, and myocardial infarction in patients presenting with chest pain. Eur Heart J 2006; 27: 2300-9.

66. Persson J, Folkersen L, Ekstrand J, et al. High plasma adiponectin concentrations is associated with all-cause mortality in patients with carotid atherosclerosis. Atherosclerosis 2012; 225: 491-6.

67. Choi SH, Ku EJ, Hong ES, et al. High serum adiponectin concentration and low body mass index are significantly associated with increased all-cause and cardiovascular mortality in an elderly cohort, "adiponectin paradox": The Korean Longitudinal Study on Health and Aging (KLoSHA). Int J Cardiol 2015; 183: 91-7.

68. Lisowska A, Lisowski P, Knapp M, et al. Serum adiponectin and markers of endothelial dysfunction in stable angina pectoris patients undergoing coronary artery bypass grafting (CABG). Adv Med Sci 2014; 59: 245-9.

69. Kręcki R, Krzemińska-Pakuła M, Peruga JZ, et al. Influence of treatment strategy on serum adiponectin, resistin and angiogenin concentrations in patients with stable multivessel coronary artery disease after oneyear follow-up. Kardiol Pol 2010; 68: 1313-20.

70. Antonopoulos AS, Margaritis M, Coutinho P, et al. Reciprocal effects of systemic inflammation and brain natriuretic peptide on adiponectin biosynthesis in adipose tissue of patients with ischemic heart disease. Arterioscler Thromb Vasc Biol 2014; 34: 2151-9.

71. Wilson SR, Sabatine MS, Wiviott SD, et al. Assessment of adiponectin and the risk of recurrent cardiovascular events in patients presenting with an acute coronary syndrome: observations from the Pravastatin Or atorVastatin Evaluation and Infection Trial-Thrombolysis in Myocardial Infarction 22. Am Heart J 2011; 161: 1147-55.

72. Ang DS, Welsh P, Watt P, Nelson SM, Struthers A, Sat$\operatorname{tar}$ N. Serial changes in adiponectin and BNP in ACS patients: paradoxical associations with each other and with prognosis. Clin Sci (Lond) 2009; 117: 41-8.

73. Jamaluddin MS, Weakly SM, Yao Q, Chen C. Resistin: functional roles and therapeutic considerations for cardiovascular disease. $\mathrm{Br} J$ Pharmacol 2012; 165: 622-32.

74. Lee TS, Lin CY, Tsai JY, et al. Resistin increases lipid accumulation by affecting class A scavenger receptor, CD36 and ATP-binding cassette transporter-A1 in macrophages. Life Sci 2009; 84: 97-104.

75. Hirai H, Satoh H, Kudoh A, Watanabe T. Interaction between resistin and adiponectin in the proliferation of rat vascular smooth muscle cells. Mol Cell Endocrinol 2013; 366: 108-16

76. Ding Q, Chai H, Mahmood N, Tsao J, Mochly-Rosen D, Zhou W. Matrix metalloproteinases modulated by protein kinase Cepsilon mediate resistin-induced migration of human coronary artery smooth muscle cells. J Vasc Surg 2011; 53: 1044-51.

77. Fang WQ, Zhang Q, Peng YB, et al. Resistin level is positively correlated with thrombotic complications in Southern Chinese metabolic syndrome patients. J Endocrinol Invest 2011; 34: e36-42.

78. Dudzinska D, Boncler M, Watala C. The cardioprotective power of leaves. Arch Med Sci 2015; 11: 819-39.

79. Chemaly ER, Hadri L, Zhang S, et al. Long-term in vivo resistin overexpression induces myocardial dysfunction and remodeling in rats. J Mol Cell Cardiol 2011; 51: 144-55. 
80. Muse ED, Feldman DI, Blaha MJ, et al. The association of resistin with cardiovascular disease in the MultiEthnic Study of Atherosclerosis. Atherosclerosis 2015; 239: 101-8.

81. Weikert C, Westphal S, Berger K, et al. Plasma resistin levels and risk of myocardial infarction and ischemic stroke. J Clin Endocrinol Metab 2008; 93: 2647-53.

82. Krecki R, Krzeminska-Pakula M, Peruga JZ, et al. Elevated resistin opposed to adiponectin or angiogenin plasma levels as a strong, independent predictive factor for the occurrence of major adverse cardiac and cerebrovascular events in patients with stable multivessel coronary artery disease over 1-year. Med Sci Monit 2011; 17: CR26-32.

83. Laurikka A, Vuolteenaho K, Toikkanen V, et al. Adipocytokine resistin correlates with oxidative stress and myocardial injury in patients undergoing cardiac surgery. Eur J Cardiothorac Surg 2014; 46: 729-36.

84. Prugger C, Luc G, Haas B, et al. Multiple biomarkers for the prediction of ischemic stroke: the PRIME study. Arterioscler Thromb Vasc Biol 2013; 33: 659-66.

85. Butler J, Kalogeropoulos A, Georgiopoulou V, et al. Serum resistin concentrations and risk of new onset heart failure in older persons: the Health, Aging, and Body Composition (Health $\mathrm{ABC}$ ) study. Arterioscler Thromb Vasc Biol 2009; 29: 1144-9.

86. Frankel DS, Vasan RS, D'Agostino RB, et al. Resistin, adiponectin, and risk of heart failure: the Framingham Offspring study. J Am Coll Cardiol 2009; 53: 754-62.

87. Fontana A, Spadaro S, Copetti M, et al. Association between resistin levels and all-cause and cardiovascular mortality: a new study and a systematic review and meta-analysis. PLoS One 2015; 10: e0120419.

88. Zhang MH, Na B, Schiller NB, Whooley MA. Association of resistin with heart failure and mortality in patients with stable coronary heart disease: data from the heart and soul study. J Card Fail 2011; 17: 24-30.

89. Qiao XZ, Yang YM, Xu ZR, Yang LA. Relationship between resistin level in serum and acute coronary syndrome or stable angina pectoris. J Zhejiang Univ Sci B 2007; 8: 875-80.

90. Lubos E, Messow CM, Schnabel R, et al. Resistin, acute coronary syndrome and prognosis results from the AtheroGene study. Atherosclerosis 2007; 193: 121-8.

91. Filipe MD, Meijers WC, van der Velde AR, Boer RA. Galectin-3 and heart failure: prognosis, prediction and clinical utility. Clin Chim Acta 2015; 443: 48-56.

92. Pugliese G, lacobini C, Pesce CM, Menini S. Galectin-3: an emerging all-out player in metabolic disorders and their complications. Glycobiology 2015; 25: 136-50.

93. Menini S, Iacobini C, Ricci C, Blasetti Fantauzzi C, Salvi L. The galectin-3/RAGE dyad modulates vascular osteogenesis in atherosclerosis. Cardiovasc Res 2013; 100: 472-80.

94. Calvier L, Miana M, Reboul P, et al. Galectin-3 mediates aldosterone-induced vascular fibrosis. Arterioscler Thromb Vasc Biol 2013; 33: 67-75.

95. Yu L, Ruifrok WP, Meissner M, et al. Genetic and pharmacological inhibition of galectin-3 prevents cardiac remodeling by interfering with myocardial fibrogenesis. Circ Heart Fail 2013; 6: 107-17.

96. Sharma UC, Pokharel S, van Brakel TJ, et al. Galectin-3 marks activated macrophages in failure-prone hypertrophied hearts and contributes to cardiac dysfunction. Circulation 2004; 110: 3121-8.

97. Sanchez-Mas, Lax A, Asensio-Lopez MC, et al. Galectin-3 expression in cardiac remodeling after myocardial infarction. Int J Cardiol 2014; 127: e98-e101.
98. Felker GM, Fiuzat M, Shaw LK, et al. Galectin-3 in ambulatory patients with heart failure: results from the HF-ACTION study. Circ Heart Fail 2012; 5: 72-8.

99. Gullestad L, Ueland T, Kjekshus J, et al. The predictive value of galectin-3 for mortality and cardiovascular events in the Controlled Rosuvastatin Multinational Trial in Heart Failure (CORONA). Am Heart J 2012; 164: 878-83.

100. Motiwala SR, Szymonifka J, Belcher A, et al. Serial measurement of galectin-3 in patients with chronic heart failure: results from the ProBNP Outpatient Tailored Chronic Heart Failure Therapy (PROTECT) study. Eur J Heart Fail 2013; 15: 1157-63.

101. Lok DJ, Lok SI, Bruggink-Andre de la Porte PW, et al. Galectin-3 is an independent marker for ventricular remodeling and mortality in patients with chronic heart failure. Clin Res Cardiol 2013; 102: 103-10.

102. Edelmann F, Holzendorf V, Wachter R, et al. Galectin-3 in patients with heart failure with preserved ejection fraction: results from the Aldo-DHF trial. Eur J Heart Fail 2015; 17: 214-23.

103. Meijers WC, Januzzi JL, deFilippi C, et al. Elevated plasma galectin-3 is associated with near-term rehospitalization in heart failure: a pooled analysis of 3 clinical trials. Am Heart J 2014; 167: 853-60.

104. Jagodzinski A, Havulinna AS, Appelbaum S, et al. Predictive value of galectin-3 for incident cardiovascular disease and heart failure in the population-based FINRISK 1997 cohort. Int J Cardiol 2015; 192: 33-9.

105. Lopez-Andres N, Rossignol P, Iraqi W, et al. Association of galectin-3 and fibrosis markers with long-term cardiovascular outcomes in patients with heart failure, left ventricular dysfunction and dyssynchrony: insights from the CARE-HF (Cardiac Resynchronization in Heart Failure) trial. Eur J Heart Fail 2012; 14: 74-81.

106. Zamora E, Lupon J, de Antonio M, et al. Renal function largely influences galectin-3 prognostic value in heart failure. Int J Cardiol 2014; 177: 171-7.

107. Anand IS, Rector TS, Kuskowski M, Adourian A, Muntendam P, Cohn JN. Baseline and serial measurements of galectin-3 in patients with heart failure: relationship to prognosis and effect of treatment with valsartan in the Val-HeFT. Eur J Heart Fail 2013; 15: 511-8.

108. Bayes-Genis A, de Antonio M, Vila J, et al. Head-tohead comparison of 2 myocardial fibrosis biomarkers for long-term heart failure risk stratification: ST2 versus galectin-3. J Am Coll Cardiol 2014; 63: 158-66.

109. van Kimmenade RR, Januzzi JL Jr, Ellinor PT, et al. Utility of amino-terminal pro-brain natriuretic peptide, galectin-3, and apelin for the evaluation of patients with acute heart failure. J Am Coll Cardiol 2006; 48: 1217-24.

110. Peacock WF. How galectin-3 changes acute heart failure decision making in the emergency department. Clin Chem Lab Med 2014; 52: 1409-12.

111. Ky B, French B, Levy WC, et al. Multiple biomarkers for risk prediction in chronic heart failure. Circ Heart Fail 2012; 5: 183-90.

112. Jaffe AS, Landt Y, Parvin CA, Abendschein DR, Geltman EM, Ladenson JH. Comparative sensitivity of cardiac troponin I and lactate dehydrogenase isoenzymes for diagnosing acute myocardial infarction. Clin Chem 1996; 42: 1770-6. 